\title{
Effects Of Different Empirical Design Approaches For Size Galleries On The Behaviour Of Rock Masses During The Excavation Operation: Excavation Case At BAE Well
}

\author{
Ismail Zaki $^{*}$, Mohamed Souissi ${ }^{\mathbf{b}}$, Khalil Abdessamad ${ }^{\mathrm{c}}$, Abdelkader Larabi ${ }^{\mathrm{d}}$ \\ ${ }^{a}$ CeDOC Ecole Mohammadia d'Ingénieurs, Rabat, Maroc. \\ b,c,dEMI, Ecole Mohammadia d'Ingénieurs, Laboratoire LAMERN, Rabat, Maroc.
}

Article History: Received: 11 January 2021; Accepted: 27 February 2021; Published online: 5 April 2021

\begin{abstract}
The characterization of rock massifs is a delicate job; indeed, it is possible to understand the behaviour of intact rocks individually by laboratory tests but it is difficult to characterize them on the whole rock mass, which has undergone a complex geological history. Empirical approaches play an important role in the excavation of galleries and the design of support systems. These approaches are considered very effective in optimizing the tunnel excavation process. Several reliable empirical approaches have been developed, but the selection or use of an appropriate empirical method to design the tunnel excavation remains a difficult task. Therefore, in this work, the analysis of four approaches, the most used, of different empirical design was carried out to determine the behaviour of the rock mass during its excavation in a state of high in situ stress. This study was carried out on the scale of the ST2 rock mass of the worksite (BAE well 3) at the Bouazzer mine. These approaches include the AFTES classification, rock mass index (RMR), rock mass quality (Q) and geological resistance index (GSI). Based on the simulated statistical results obtained from said empirical approaches, through the finite element calculation, it was found that the application of the rock mass quality approach is very efficient in the excavation of the rock mass. gallery of size because it makes it possible to take into account the equivalent dimensions of the gallery, the stress condition in situ due to the excavation and the heights of overburden which are considered as major elements of the stability of the gallery. The method provides an optimized reinforcement and support design. In addition, this study will serve as a valuable basic document for the geotechnical engineer to design and plan support systems in the excavation of galleries under high in-situ stress.
\end{abstract}

Keywords: Numerical Modeling, Rock Mass, Finite Element Methods Empirical Approach, Characterization, Gallery, PHASE 2, Rock Mass ST2..702540

\section{Introduction}

The structural analysis and the study of the mechanical behaviour of the rock mass are essential steps for the characterization. The rock mass is often affected by stresses, fractures, discontinuities or weak planes which degrade its mechanical characteristics and promote its state of deterioration. None of the current methods can claim to solve the infinite number of cases that are available to the geotechnical engineer.

The empirical approach tries to provide us with the benefit of past and successful experiences. To do so, it is necessary to find in these experiments the real case closest to the studied case. The researchers proceeded to the classification of these experiments by means of a certain number of parameters preponderant to the stability of the structures. Several classifications exist. Each of them has its own particularities and meets a number of requirements.

Classification of rock masses has generally been a widely used method because it has been simple, proven, and reliable for over three decades (Goel and Singh 2011). Since the first rock mass classification system established by Terzaghi and White (1946), many empirical classifications have been proposed for certain geological conditions.

Thus, we find The new Austrian method of tunneling (NATM) [1], known in the United States as the sequential excavation method (SEM) and in the United Kingdom as the shotcrete lining (SCL), appeared in 1960, is based on understanding the reaction of rock to the creation of a tunnel. The Rock Mass Index (RMi) [2] which uses certain parameters inherent in the rock mass which are combined to express the resistance index relative to the rock mass. The Rock Structure Index (RSR) [3] which is a quantitative method to describe the quality of a rock and to select the appropriate support. In 1994, China promulgated (GB50218-94) "Rock mass technical classification standard": It includes the basic classification of rock mass quality applicable to assess the quality of rock mass and identification of class of rock masses intended to revise the basic quality index (BQ) [4] in collaboration with specific engineering companies. The index $(\mathrm{BQ})$ is thus defined by the degree of hardness of the rock and the index of rock mass integrity. 
However, for our study, we adopted the approaches in force the most used, namely: the quality of the rock mass (Q) [5], the geological resistance index (GSI) [6], the classification of 1 'AFTES [7] and the index of the rock mass (RMR) [8] as empirical approaches for the characterization of the rock mass ST2, under conditions of high in-situ stress and to evaluate its support system, located at the level of the BAE p3 worksite in the BouAzzer mine, Morocco.

In this regard, the excavation and support systems were analyzed using all empirical design approaches of the study. Subsequently, the selected excavation and support system was simulated, for each empirical design approach, with in situ site conditions specific to BAE P3 in the finite element method.

Among the different approaches, the design method which provided the most controlled deformations compared to the other methods was chosen as the most suitable method for the excavation of the gallery for the specific conditions of the site.

\section{Presentation of the Bouazzer-EST Site}

\subsection{Project Summary}

The Bouazzer EST PIII deposit is located approximately $2 \mathrm{~km}$ east of the Bouazzer mining centre. The ST2 structure is the main structure operated. It has an average extension of $160 \mathrm{~m}$ in length and a power that varies between $0.5 \mathrm{~cm}$ and $2.7 \mathrm{~m}$. This structure is generally oriented NE-SW with a subvertical dip. It is recognized up to a depth of $-560 \mathrm{~m}$. Its operation was stopped due to permanent geotechnical instabilities; however, it will be resumed given its large metal tonnage.

The mineralization of the ST2 structure at Bouazzer-Est is in vein form, which develops downstream $-510 \mathrm{~m}$ in a variable geological context (diorite, serpentine). It is a contact structure (Figure 1) which makes it difficult to operate without setting up a prior support. The exploitation of the structure reached the state of exhaustion at the $510 \mathrm{~m}$ level as illustrated at the level of (Figure 2) by marking difficulties namely the instabilities and fracturing of the rock mass, which concerned the adoption several support methods: timbering, shotcrete, metal hangers, netting and bolting.

At level $-560 \mathrm{~m}$, the advancement of the gallery experienced harmful problems especially during firing, bulky blocks tending to fall and in large quantities, which required the installation of a reinforced concrete vault just below. Entrance to the excavation. Then metal hangers with wood trim continued the advancement, the tracing began with wooden frames plus metal hangers.

The study of the excavations between the $-510 \mathrm{~m}$ and $-560 \mathrm{~m}$ levels shows facies consisting mainly of altered chloritized quartz diorites fractured in contact with blunt serpentines. At this contact, we find cobalt-rich mineralization consisting of skutterudite and safflorite and sometimes lôllingite. Front sections were made at the $560 \mathrm{~m}$ level illustrating this contact (Figure 3). The characterization study at the $-560 \mathrm{~m}$ level will therefore focus mainly on contact rocks, namely: altered chloritized and fractured quartz diorites, serpentines and mineralization.

The progress of the exploitation works in the ST2 of the Bouazzer EST site therefore depends on the stability of the underground structures, hence the importance of the geotechnical study, which makes it possible to find the optimal support solutions based on the characterization of the rocky massifs surrounding these excavations.

The fundamental contribution of this project is to establish a support solution at the $-560 \mathrm{~m}$ level, for the downstream exploitation of the ST2 mineralized structure of Bouazzer East by evaluating the contribution of each empirical approach. In the end, the solution adopted must meet the requirements of safety, productivity plus the economic constraint, which represents a factor for the success of the project.

\subsection{Site Geology}

The site is part of the Bouazzer El Graara buttonhole, which is essentially made up of Precambrian terrain, including an ophiolitic series, which mainly hosts cobalt and chromium mineralization. The buttonhole layout is shown in Figure 4.

The Bouazzer buttonhole is of significant mining interest given its history, its significant coral mineralization and its particular geology. It consists of a Proterozoic age base and an Infracambrian cover resting on this base. 
The location of the BouAzzer-Est site is illustrated in Figure 5. The local geological context of the area is characterized by the outcrop of the Lower Precambrian II terrains, represented by serpentines in contact with quartz diorites (Figure 6).

At the $-510 \mathrm{~m}$ level, the mineralization of the ST2 structure is NE-SW direction, characterized by a strong dip towards the SE about $80^{\circ}$, it is a subvertical structure towards the serpentines which leaves the advantage that the serpentines are found in wall and diorites on the roof.

At the $-560 \mathrm{~m}$ level, the mineralization of the ST2 structure is NW-SE direction, characterized by an average dip towards the $\mathrm{NE}$ which is about $60^{\circ}$ towards the serpentines which gives serpentines on the roof this time and diorites on the wall. . The geological study shows that the direction of the dip of the serpentine has changed between the $-510 \mathrm{~m}$ and $-560 \mathrm{~m}$ levels as shown in Figure 1, knowing that these serpentines are schistose and the schistosity planes have a subvertical dip towards the SE, which generated landslide problems in the first phases of operation of the $-560 \mathrm{~m}$ level.Top: $3,3 \mathrm{~cm}$.

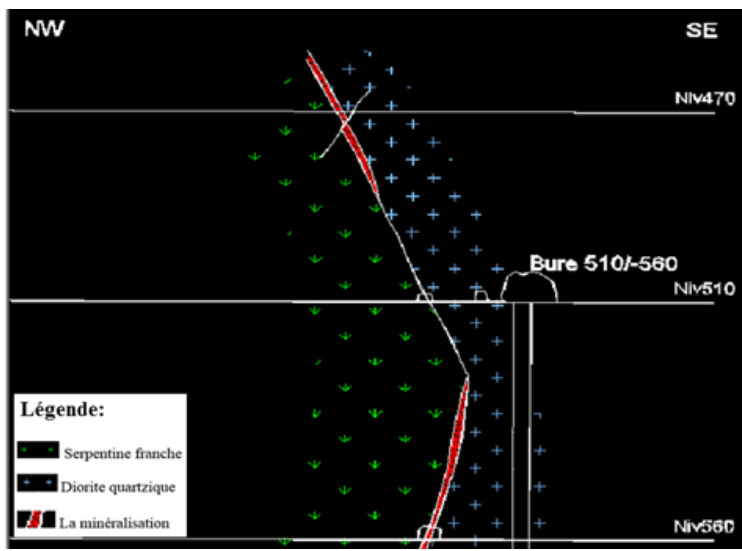

Figure 1. Cross section shows the contact of the serpentines with the diorites; the mineralization is at the contact level.

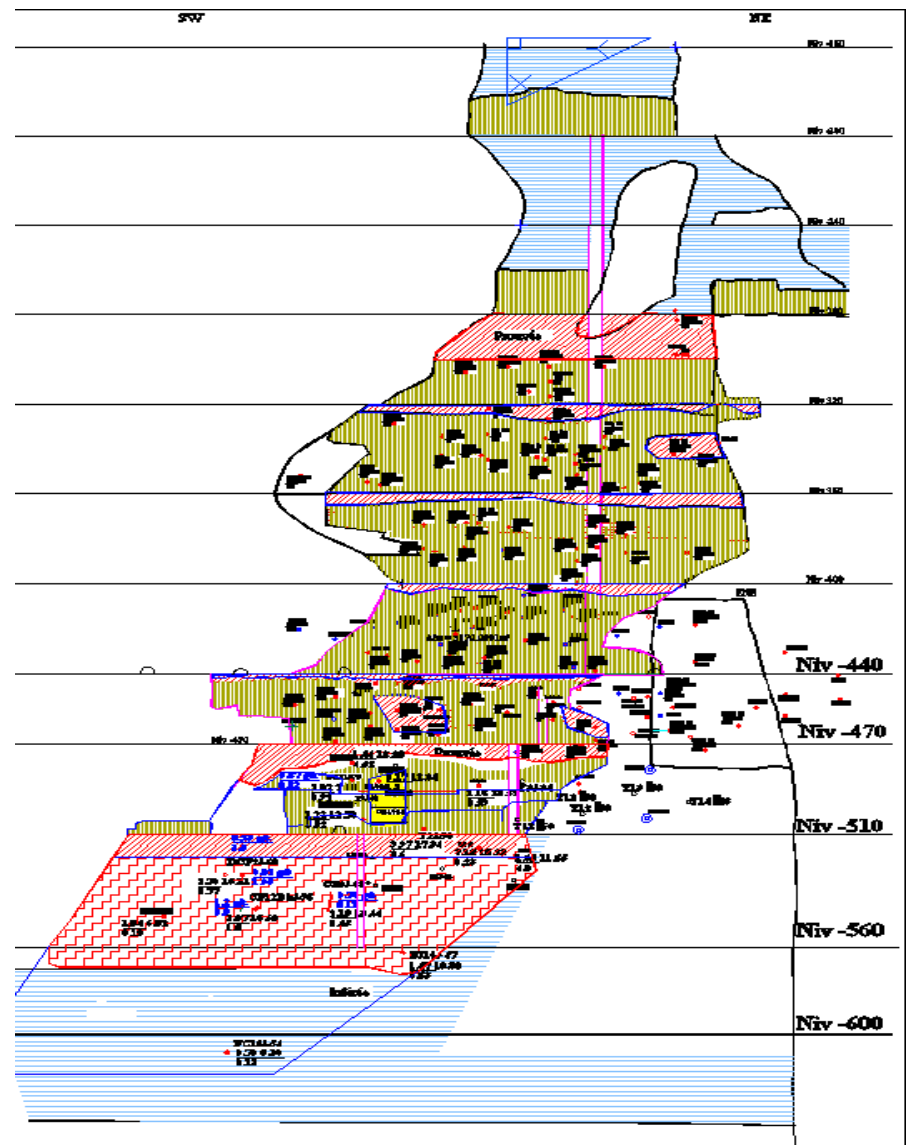


Effects Of Different Empirical Design Approaches For Size Galleries On The Behaviour Of Rock Masses During The Excavation Operation: Excavation Case At BAE Well

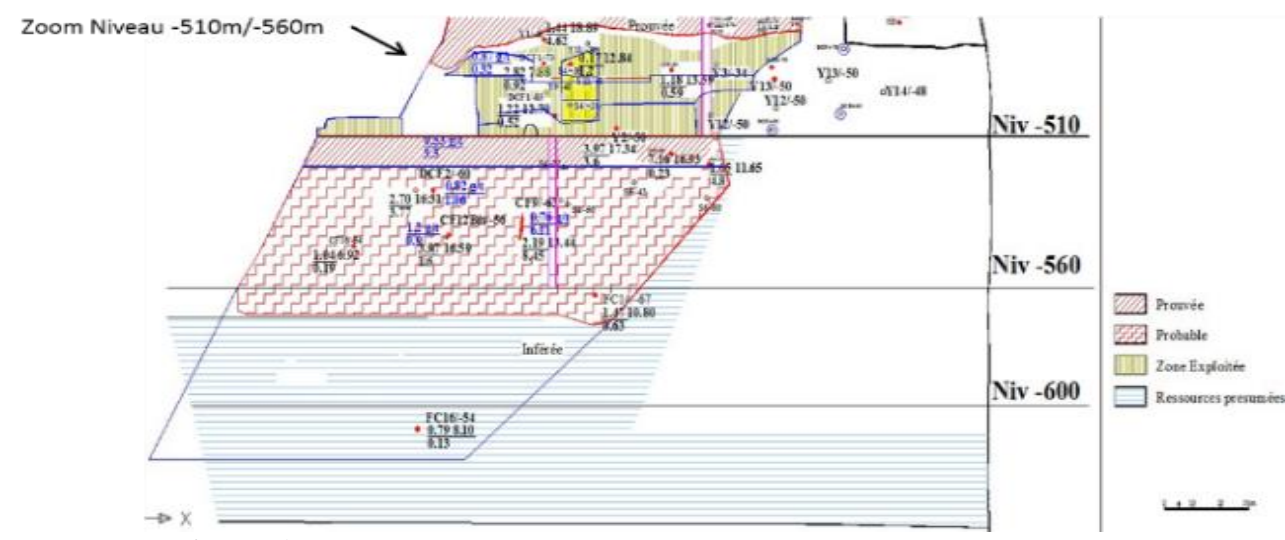

Figure 2. Longitudinal section of the ST2 structure at Bouazzer Est.
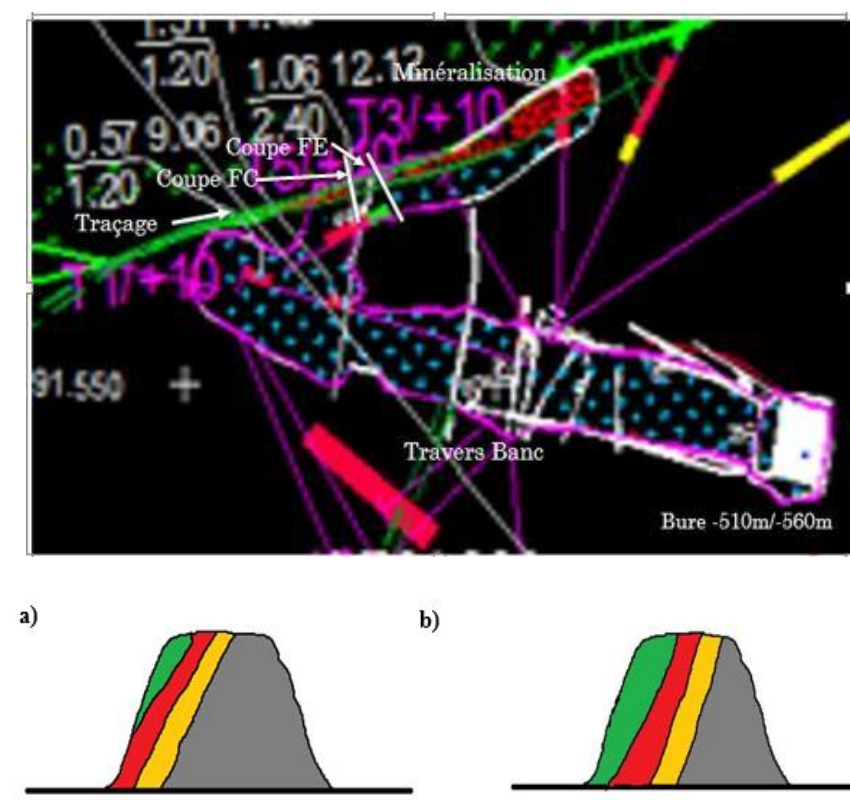

b)

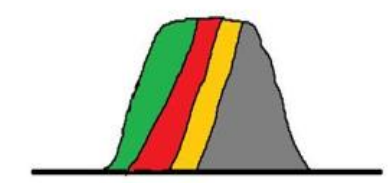

- Diorite quartzique + Chlorites

Diorite + sulfures

- Cobalt + Chlorites

- Serpentines Franche

Figure 3. Front cuts made at level-560: (1) Plan of level -560m location of cuts at tracing level; (2) Front cuts: a) FE cut. b) FC cut,

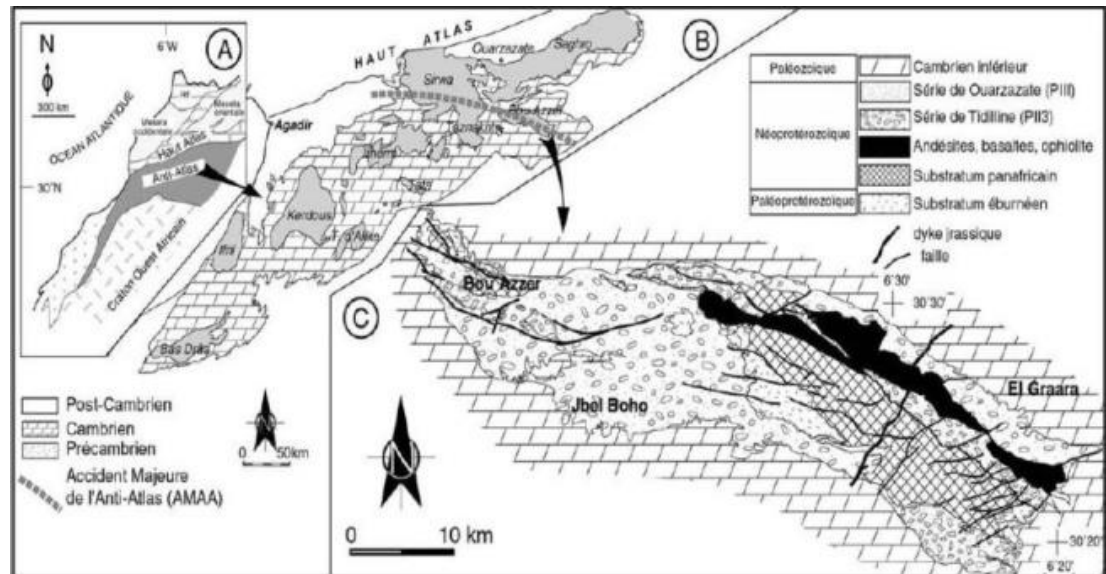

Figure 4. (A) The major structural areas of Morocco; (B) Geological diagram of the Anti-Atlas; (C) Simplified geological map of the Bouazzer - El Graara buttonhole 


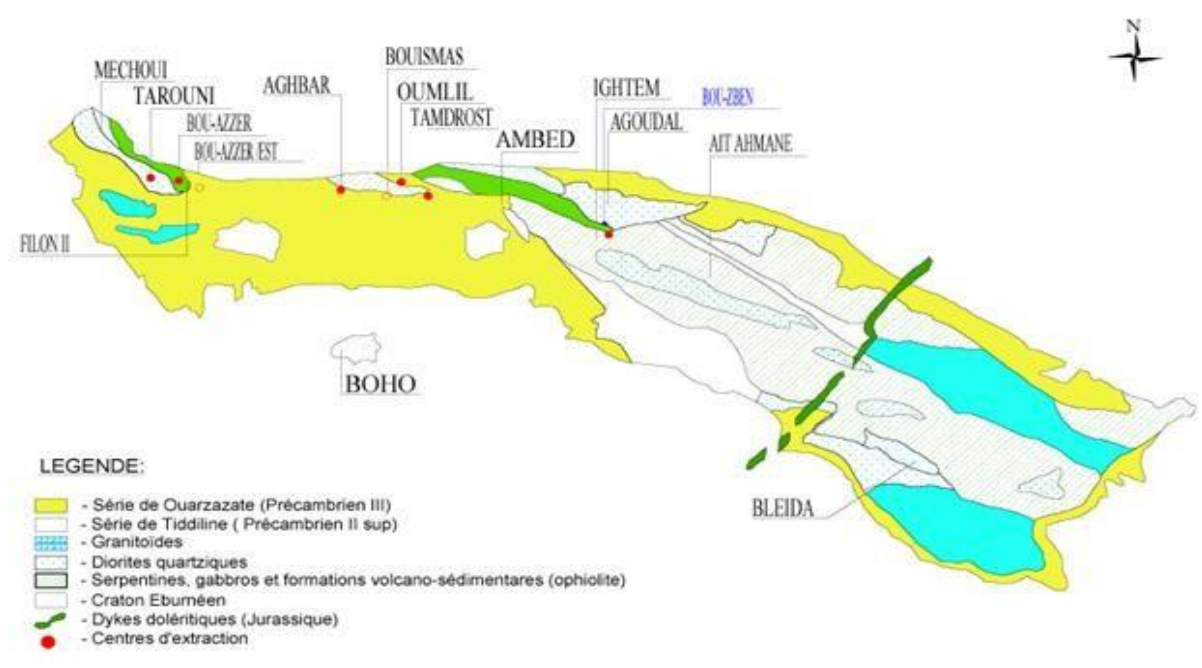

Figure 5. Geological map of the Bouazzer buttonhole illustrating the location of the Bou Azzer-Est site

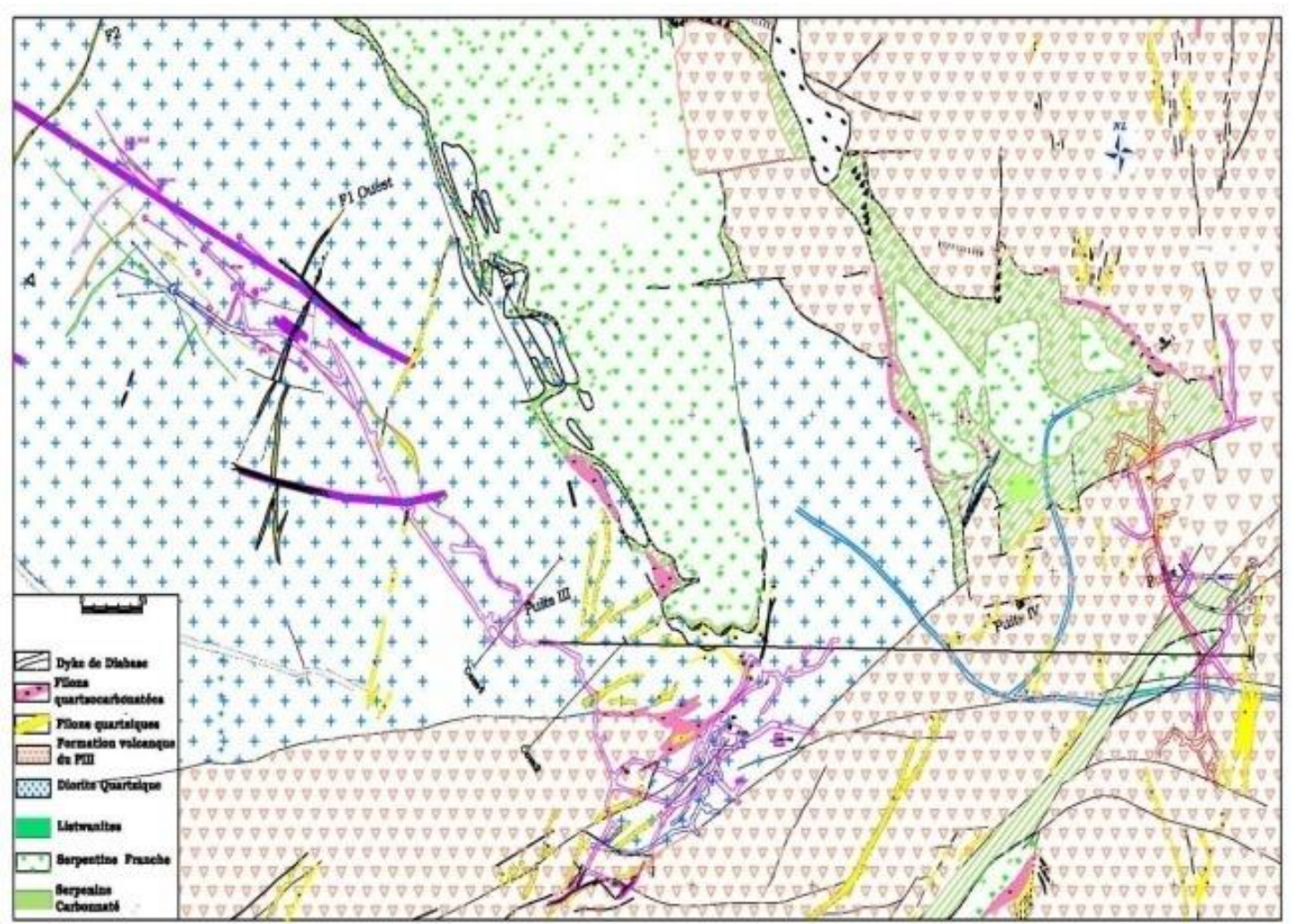

Figure 6. Geological surface survey of Bouazzer Est

\section{Excavation of the Size Gallery and Design of the Support}

\subsection{Size Gallery Empirical Design Approach}

The "quality of the rock mass" (Q-system) was used to design the excavation and support system for the waist gallery at level (-560) of the BAE p3 site. The main parameters and procedures adopted in the design of the tunnel excavation and support system are explained in the following sections.

The predominantly known rock mass quality with the Q system was first introduced by Barton et al. [5] in 1974 at the Norwegian Geotechnical Institute (NGI) and improved by characterization and classifications in 1993 by Grimstad [9]. This has been further optimized by Barton [10]. The Q system was based on six parameters, each with a specialized characteristic and rating. Q values are based on a semi-logarithm and values between 0.001 (being exceptionally low-grade rock) to 1000 (being exceptionally strong grade rock). The equation as defined by Barton [5] is given below: 


$$
Q=\left(\frac{R Q D}{J n}\right) *\left(\frac{J r}{J a}\right) *\left(\frac{J w}{S R F}\right)
$$

Or:

Jn is a number characterizing the set formed by the families of joints.

Jr characterizes the roughness of the joints.

Ja characterizes the deterioration of the joints.

$\mathrm{JW}_{\mathrm{W}}$ is the hydraulic reduction factor of the joints.

SRF is the Stress Reduction Factor.

RQD is Deere's Rock Quality Designation.

In order to be able to relate the parameter $\mathrm{Q}$ to recommendations for support in underground structures, Barton $\&$ al have defined an additional quantity, which they call the equivalent dimension of the excavation: From, with:

$$
D e=\frac{\text { Largeur, Hauteur }(m)}{E S R}
$$

ESR (Excavation Support Ratio): being a factor depending on the purpose of the excavation, in other words, the degree of security sought for the stability as shown in Table 1.

Table 1. ESR values according to the Nature and type of the structure.

\begin{tabular}{lll}
\hline \multicolumn{1}{c}{ Type of work } & \multicolumn{1}{c}{ work } & \multicolumn{1}{c}{ ESR } \\
\hline Permanent mining excavations & Cross benches, pilot galleries used for sinking large excavations & 1,6 \\
Temporary mining excavations & Size galleries, production site & 3 à 5 \\
Engineering worksCivil & Tunnels, underground storage, underground structures & 1,3 à 0,8 \\
Vertical wells & Circular section & 2,5 \\
Vertical wells & Rectangular / square section & 2 \\
\hline
\end{tabular}

Using core drillings and field observation, we were able to classify the rock mass of ST2 according to the Barton classification, by calculating the $\mathrm{Q}$ for the three types of rock that were identified: Altered quartz diorite chloritized fractured, Free serpentine, Mineralized case + chlorite. The values of Q for each facies are shown in Table 2.

We considered the maximum opening of the gallery of size equal to 6 meters, and the ESR at 2 (Temporary mining excavations). So, we get a value $\mathrm{De}=2$.

Table 2. Q index for different types of rocks: Altered, chloritized fractured quartz diorite; Straight serpentine; Mineralized case + chlorite.

\begin{tabular}{ll}
\hline Rock & Q \\
\hline Altered chloritized fractured quartz diorite & 2,67 \\
Frank serpentine & 0,22 \\
Mineralized case + chlorite & 1,6 \\
\hline
\end{tabular}

\subsection{Geomechanical properties of the different types of rock in the size gallery}

The properties of the different rocks are illustrated in Table 3 with the parameters of the generalized Hoek and Brown failure criterion [11] and the Poisson's ratio.

Table 3a. Properties of the different types of rocks: Parameters of the generalized Hoek and Brown failure criterion

\begin{tabular}{lllll}
\hline \multirow{2}{*}{ Rock } & \multicolumn{1}{c}{$\begin{array}{c}\text { Altered chloritized fractured } \\
\text { quartz diorite }\end{array}$} & $\begin{array}{c}\text { Mineralized case }+ \\
\text { chlorite }\end{array}$ & $\begin{array}{c}\text { Frank } \\
\text { serpentine }\end{array}$ \\
\hline Hoek- Brown & $\mathrm{mb}$ & 4,952 & 3,962 & 0,617 \\
parameters & $\mathrm{s}$ & 0,0107 & 0,0107 & 0,0002 \\
& $\mathrm{a}$ & 0,502 & 0,502 & 0,515 \\
Young's modulus & $\mathrm{Em}(\mathrm{Mpa})$ & 18839,15 & 18839,15 & 1804,1 \\
\hline
\end{tabular}


Table 3b. Properties of the different types of rocks: Poisson's ratio.

\begin{tabular}{ll}
\multicolumn{1}{c}{ Rock } & Coefficient de poisson \\
\hline Diorites & 0,25 \\
Mineralized case & 0,22 \\
Frank serpentines & 0,20 \\
Backfill & 0,15 \\
\hline
\end{tabular}

\section{Numerical Simulation of the Size Gallery Deformation}

The simulation of the deformation in the size gallery (-560) of the BAE P3 site was carried out using numerical simulation by the finite element method (FEM) using PHASE 2D [12]. In this regard, the following steps have been taken.

\subsection{Model establishment phase}

It is the phase of construction of the geometry of the model, in which one defines the number of stages and the mechanical and structural characteristics of the different types of materials "ore, slab, backfill, wall" as well as the type of initial stresses (gravitational or constant) prevailing in the virgin massif and the boundary conditions. There should be a spacing before of 24-point.

\subsubsection{General Assumptions}

- We consider the following hypotheses:

- The strains are considered plane.

- We did not take into account the infrastructure assuming that its effect on the operating area is negligible.

- The soils consist mainly of altered chloritized fractured quartz diorites and carbonate frank serpentines.

- Longitudinal displacements are zero (displacement along the Y axis) on both left and right sides of the model.

\subsubsection{Model Generation}
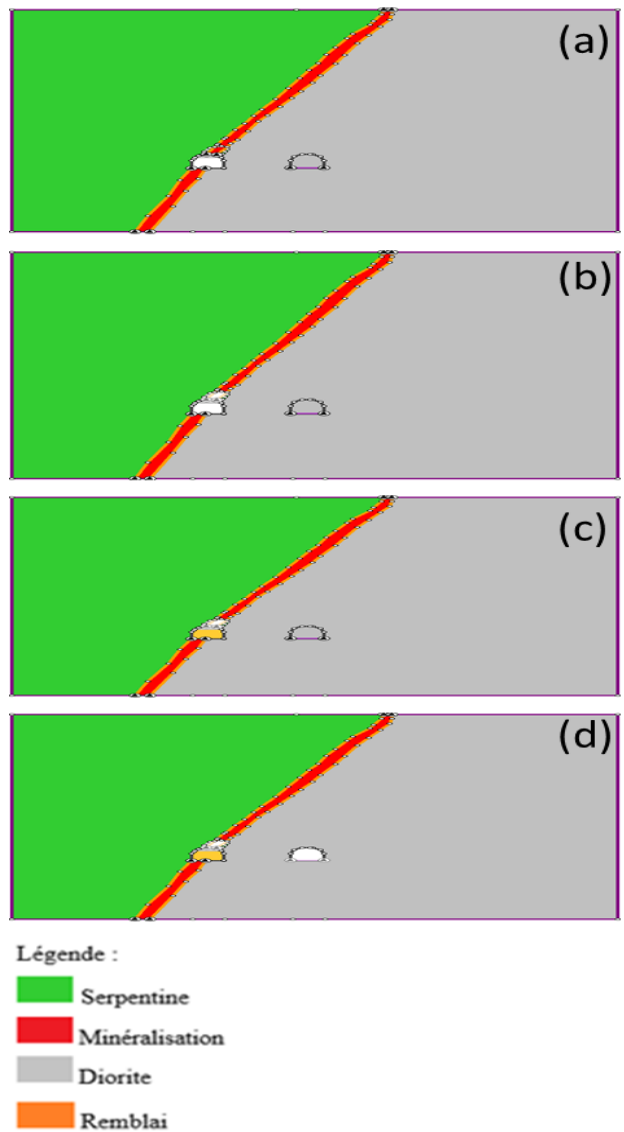

Figure 7. Geometric model of the cross section: (a) Stage 1; (b) Stage 2; (c) Stage 3; (d) Stage 4 
The model chosen represents a transverse section between the $-510 \mathrm{~m}$ and $-560 \mathrm{~m}$ levels, which shows the mineralization in contact between the diorites and the serpentines, the model was divided into four stages.

At the first stage, we open an excavation $2.5 \mathrm{~m}$ high and $2.5 \mathrm{~m}$ wide limited by the two rock walls of quartzic and serpentine diorites. The mineralization is limited by the two major $60^{\circ}$ dip joints. In the second stage, the slice of the ore located above is cut down, which gives an opening $1.7 \mathrm{~m}$ high and $1.7 \mathrm{~m}$ wide more. At the third stage, the first excavation is backfilled to a depth of $2 \mathrm{~m}$. Another excavation is opened at the fourth stage, next to the first $2.5 \mathrm{~m}$ high and $2.5 \mathrm{~m}$ wide to study the effect of the service on the size. The different stages are illustrated in Figure 7.

The different material properties have been described in section 3.2.

\subsubsection{Estimation of in Situ Stresses}

The base of the model has the ordinate +17.5 along the $\mathrm{Y}$ axis. So the overburden is observed at:

$560-17.5=542.5 \mathrm{~m}$. The empirical relation defined by Hoek and Brown [13] as stipulated in equation (3) calculated the in situ vertical stress $(\sigma \mathrm{v})$.

$$
\sigma \mathrm{v}=0.027 \mathrm{Z}(\mathrm{MPa})
$$

Where " $\mathrm{Z}$ " is the height of the overburden in meters above the waist gallery to the ground surface. Sheorey [14] proposed the equation for the horizontal to vertical stress ratio " $\mathrm{K}$ " as shown below:

$$
K=0.25+7 E h[0.001+1 / Z]
$$
(5):

Where "Eh" is the mean modulus of strain in GPa. Then the horizontal stress ( $\sigma \mathrm{h})$ was calculated with equation

$$
\sigma \mathrm{h}=\mathrm{K} \sigma \mathrm{V}
$$

In which, the GSI was determined with respect to the rock condition of the site on the principles and guidelines defined by Hoek and Brown [15], various minor discontinuities, including cracked, fractured joints, were also taken into account in the rock mass through the GSI as defined by Hoek. "Ei" is the elastic modulus of intact rock and calculated from the following equation as defined by Deere [16]:

$$
\mathrm{Ei}=\mathrm{MR} \sigma \mathrm{ci}
$$

"MR" is the modulus ratio as established by Deere [16], while "ఠci" is the uniaxial compressive strength of the rock taken from [17].

Based on the above relationships, the in situ stress state conditions in the waist gallery $(-560)$ were calculated and assembled in Table 4.

Table 4. In-situ stresses defined at the level of the size gallery (-560) at BAE p3

\begin{tabular}{ll}
\hline \multicolumn{1}{c}{ Description } & \multicolumn{1}{c}{ Détails } \\
\hline Opening of the gallery along the spring line & $2.5 \mathrm{~m}$ \\
Overburden height & $542,5 \mathrm{~m}$ \\
Horizontal / vertical ratio $(\mathrm{K})$ & 1,2 \\
Vertical stresses $(\sigma \mathrm{z})$ & $14.64 \mathrm{Mpa}$ \\
Horizontal stresses $(\sigma \mathrm{x})$ & $17.57 \mathrm{Mpa}$ \\
\hline
\end{tabular}

\section{Evaluation of Different Empirical Design Approaches for the Excavation of the Waist Gallery at Level-560 at BAE P3}

In this section, four empirical design approaches for the excavation and the support system were analysed for the shaft excavation.

\subsection{Numerical Simulation Phase Using the AFTES Classification}

The Association Française des Travaux en Souterrain (AFTES) was created in January 1972 to respond to the recommendations of the International Conference on Underground Works held in Washington in 1970, which recommended the establishment in each country of an organization bringing together the various actors involved, in various capacities, in underground work. 
Rather than giving the massif an overall "score" determining the conditions for excavating a structure, AFTES preferred to clearly specify the various factors that must be known for the design of an underground project in a rocky massif. Table 5 summarizes the different types of supports retained by the AFTES recommendation for the different types of rocks.

Table 5. The support obtained from the use of AFTES for ST2 $(-560 \mathrm{~m})$.

\begin{tabular}{llll}
\hline \multicolumn{1}{c}{ Rock } & \multicolumn{1}{c}{$\begin{array}{c}\text { Altered chloritized } \\
\text { fractured quartz diorite }\end{array}$} & \multicolumn{1}{c}{ Frank serpentine } & \multicolumn{1}{c}{$\begin{array}{c}\text { Mineralized case }+ \\
\text { chlorite }\end{array}$} \\
\hline \multirow{2}{*}{$\begin{array}{l}\text { The supports } \\
\text { given by }\end{array}$} & Shotcrete & Shotcrete & Shotcrete \\
AFTES & Point anchor bolts & Point Anchor Bolts & Point Anchor Bolts \\
& Distributed anchor bolts & Distributed Anchor Bolts & Distributed Anchor \\
& Heavy hangers. & Heavy hangers & Bolts \\
\end{tabular}

\subsection{Numerical Simulation Using the Quality of the Rock Mass (Q System)}

The quality of the rock mass (Q) was defined previously in section 3 at the level of equation 1 . Thus, its calculation for the different types of rocks showed that the altered quartz diorite chloritized fractured and the (mineralized case + chlorite) are of poor quality and the fresh serpentine of very poor quality. Table 6 summarizes the types of support proposed by the Barton classification.

Table 6. The support obtained from the use of AFTES for ST2 $(-560 \mathrm{~m})$

\begin{tabular}{|c|c|c|c|c|}
\hline Rock & $\begin{array}{c}\mathrm{Q} \\
\text { Systéme }\end{array}$ & $\begin{array}{c}\text { Barton } \\
\text { classification }\end{array}$ & De & Support \\
\hline $\begin{array}{l}\text { Altered chloritized } \\
\text { fractured quartz diorite }\end{array}$ & 2,67 & Poor & 2 & Bolting $\mathrm{Lb}=1,6 \mathrm{~m} / \mathrm{Es}=1,35 \mathrm{~m}$ \\
\hline Mineralized case + chlorite & 1,6 & Poor & 2 & Bolting; $\mathrm{Lb}=1,6 \mathrm{~m} / \mathrm{Es}=1,35 \mathrm{~m}$ \\
\hline Serpentine & 0,22 & Very poor & 2 & Wire mesh + shotcrete $50-90 \mathrm{~mm}$ with bolting \\
\hline
\end{tabular}

\subsection{Numerical Simulation Using the Rock Mass Index (RMR)}

Following the RMR89 approach, the rock mass of ST2 was classified by the Bieniawski method. So, the altered chloritized fractured quartz diorite and the (mineralized case + chlorite) are of medium quality, while the fresh serpentine is of poor quality. The recommended supports for the different facies according to the RMR89 index are given in Table 7 .

Table 7. Support recommendations according to the Bieniawski classification for the three facies of ST2.

\begin{tabular}{|c|c|c|c|c|c|c|c|}
\hline \multirow{2}{*}{ Class } & \multicolumn{2}{|c|}{$\begin{array}{l}\text { Types de soutènement } \\
\text { Anchor bolt }\end{array}$} & \multicolumn{3}{|c|}{ Shotcrete } & \multicolumn{2}{|l|}{ Metal hangers } \\
\hline & $\begin{array}{l}\text { Bolt } \\
\text { spacing }\end{array}$ & $\begin{array}{l}\text { Support } \\
\text { supplement }\end{array}$ & Vaulted & Piers & $\begin{array}{l}\text { Support } \\
\text { supplement }\end{array}$ & Type & Spacing \\
\hline $\begin{array}{l}\text { Altered } \\
\text { chloritized } \\
\text { fractured } \\
\text { quartz diorite }\end{array}$ & $1-1.5 \mathrm{~m}$ & $\begin{array}{l}\text { Mesh plus } 30 \\
\text { mm shotcrete } \\
\text { vault if } \\
\text { necessary }\end{array}$ & $100 \mathrm{~mm}$ & $50 \mathrm{~mm}$ & $\begin{array}{l}\text { Occasionally } \\
\text { trellis and } \\
\text { bolts }\end{array}$ & $\begin{array}{l}\text { Lightweight } \\
\text { hangers }\end{array}$ & $\begin{array}{l}1.5 \text { à } 2 \\
\mathrm{~m}\end{array}$ \\
\hline $\begin{array}{l}\text { Mineral } \\
\text { crate+ } \\
\text { chlorite }\end{array}$ & $1-1.5 \mathrm{~m}$ & $\begin{array}{l}\text { Mesh plus } 30 \\
\text { mm shotcrete } \\
\text { vault if } \\
\text { necessary }\end{array}$ & $100 \mathrm{~mm}$ & $50 \mathrm{~mm}$ & $\begin{array}{l}\text { Occasionally } \\
\text { winches and } \\
\text { bolts }\end{array}$ & $\begin{array}{l}\text { Lightweight } \\
\text { hangers }\end{array}$ & $\begin{array}{l}1.5 \text { à } 2 \\
\mathrm{~m}\end{array}$ \\
\hline $\begin{array}{l}\text { Frank } \\
\text { serpentine }\end{array}$ & Not reco & imended & $200 \mathrm{~mm}$ & $150 \mathrm{~mm}$ & $\begin{array}{l}\text { Lattice bolts } \\
\text { and light } \\
\text { hangers }\end{array}$ & $\begin{array}{l}\text { Immediately } 80 \\
\text { mm of BP then } \\
\text { heavy hangers to } \\
\text { advancement }\end{array}$ & $0.7 \mathrm{~m}$ \\
\hline
\end{tabular}

\subsection{Numerical Simulation Using the Geological Resistance Index (GSI)}

Introduced by Hoek [6] and Kaiser and Bawden (1995), the GSI is a dimensionless number, determined empirically, which varies between 5 and 85 , and which can be estimated from an examination of the quality of the rock mass. in situ. The GSI method is therefore based on direct observation of the structure of the rock mass. The GSI estimate was chosen from the graph defined by Hoek [20]. 
However, the GSI system does not define the waist gallery reinforcement and support system. To estimate the support, a correlation was extracted from GSI with RMR to define the reinforcement system. Hoek and Brown [15] defined the correlation between RMR and GSI as shown in equation (7):

$$
\text { RMR89 }=\text { GSI }+5
$$

From the description of the facies structures, we obtain the GSI number for each of the facies subject to the study. Thus, we have an RMR89 equal to 70 for the altered quartz diorite chloritized fractured and the mineralized + chlorite case and an RMR89 equal to 45. According to Bieniawski's classification, the altered chloritized fractured quartz diorite and the (mineralized case + chlorite) are of class 2 therefore of a Good quality, while the fresh serpentine and of Class 3 therefore of average quality. The recommended supports for the different facies according to the RMR89 index are given in Table 8.

Table 8. Support recommendations according to the Bieniawski classification for the three facies of ST2.

\begin{tabular}{|c|c|c|c|c|c|c|c|}
\hline \multirow{3}{*}{ Class } & \multicolumn{5}{|c|}{ Types of support } & \multirow{2}{*}{\multicolumn{2}{|c|}{ Metal hangers }} \\
\hline & \multicolumn{2}{|c|}{ Anchor bolt } & \multicolumn{3}{|c|}{ Shotcrete } & & \\
\hline & $\begin{array}{l}\text { Spacing } \\
\text { bolting }\end{array}$ & $\begin{array}{l}\text { Support } \\
\text { supplement }\end{array}$ & Vaulted & Piers & $\begin{array}{l}\text { Support } \\
\text { supplement }\end{array}$ & Type & Spacing \\
\hline $\begin{array}{l}\text { Chloritised } \\
\text { fractured } \\
\text { altered quartz } \\
\text { diorite }\end{array}$ & $1.5-2 \mathrm{~m}$ & $\begin{array}{l}\text { Occasional } \\
\text { trellis captivates }\end{array}$ & $50 \mathrm{~mm}$ & None & None & uneconomical & \\
\hline $\begin{array}{l}\text { mineralized } \\
\text { case + chlorite }\end{array}$ & $1.5-2 \mathrm{~m}$ & $\begin{array}{l}\text { Occasional } \\
\text { trellis captivates }\end{array}$ & $50 \mathrm{~mm}$ & None & None & uneconomical & \\
\hline $\begin{array}{l}\text { Frank } \\
\text { serpentine }\end{array}$ & $1-1.5 \mathrm{~m}$ & $\begin{array}{l}\text { Mesh plus } 30 \\
\text { mm of shotcrete } \\
\text { in the vault if } \\
\text { necessary }\end{array}$ & $100 \mathrm{~mm}$ & $\begin{array}{l}50 \\
\mathrm{~mm}\end{array}$ & $\begin{array}{l}\text { Occasionally } \\
\text { latticework and } \\
\text { bolts }\end{array}$ & $\begin{array}{l}\text { Lightweight } \\
\text { hangers }\end{array}$ & $\begin{array}{l}1.5 \text { à } 2 \\
\mathrm{~m}\end{array}$ \\
\hline
\end{tabular}

\section{Discussion of Results}

Since we want to ensure the support of the gallery, metal hangers cannot be chosen as a means of support. Thus, waist bolting or serpentine side shotcrete are retained as a support solution. The application of these means of support in the field shows satisfactory results for the Q-System method compared to that of other methods where simulation with MEF confirms it. The method is suitable because it takes into account the equivalent dimensions of the size gallery when defining the support system. This functionality is not available in any other design approach. In addition, the efficiency of the $\mathrm{Q}$ system is further increased because the method takes into account the effective in-situ stress and the overload height during excavation.

\section{Conclusion}

Among the different design approaches, the RockQualityIndex (Q-system) was found to be the most suitable method for application in the excavation of the waist gallery taking into account the control of the deformation of the rock mass. The majority of empirical methods ignored the effective gallery width, in situ stress conditions and overburden heights which are considered to be major elements in the stability of the size gallery and the determination of the support. Only Q-system, RMR14 respond to the stress effect, in which the Q-System was found to be highly suitable in this regard. In addition, the design of the support system at the size galleries experiencing high in situ stresses can be better evaluated in the future on the basis of this study.

\section{References}

1. NATM, Austrian Standards On B 2203-1 And-2 For Underground Works, Felsbau 21.

2. Palmström, A. (1996). The Rock Mass Index (RMĐ Applied In Rock Mechanics And Rock Engineering.

3. Wickham, G.E., Tiedemann, H., \& Skinner, E.H. (1972). Support Determinations Based On Geologic Predictions. In N Am Rapid Excav \& Tunnelling Conf Proc., 1.

4. Standard For Engineering Classification Of Rock Masses. The National Department Of Technical Monitorial Affairs And The.

5. Barton, N., Lien, R., \& Lunde, J. (1974). Engineering Classification Of Rock Masses For The Design Of Tunnel Support. Rock Mechanics, 6(4), 189-236.

6. Hoek, E. (1994). Strength Of Rock And Rock Masses. ISRM News Journal, 2(2), 4-16.

7. Bissonnais, H.L. 4.1.2. Characterization Of The Massif, 119. 
8. Bieniawski, Z.T. (1973). Engineering Classification Of Jointed Rock Masses. Civil Engineer In South Africa, 15(12).

9. Grimstad, E. (1993). Updating The Q-System For NMT. In Proceedings Of The International Symposium On Sprayed Concrete-Modern Use Of Wet Mix Sprayed Concrete For Underground Support, Fagemes, Oslo, Norwegian Concrete Association, 1993.

10. Barton, N. (2002). Some New Q-Value Correlations To Assist In Site Characterisation And Tunnel Design. International Journal Of Rock Mechanics And Mining Sciences, 39(2), 185-216.

11. Eberhardt, E. (2012). The Hoek-Brown Failure Criterion. Rock Mechanics And Rock Engineering, 45(6), 981-988. Https://Doi.Org/10.1007/S00603-012-0276-4

12. Phase2_Tutorialmanual.Pdf ». Consulté Le: Avr. 30, 2020. [En Ligne]. Disponible Sur: Https://Www.Rocscience.Com/Downloads/Phase2/Phase2_Tutorialmanual

13. Brown, E.T., \& Hoek, E. (1978). Trends In Relationships Between Measured In-Situ Stresses And Depth. In International Journal Of Rock Mechanics And Mining Sciences \& Geomechanics Abstracts, 15(4), 211-215.

14. Sheorey, P.R. (1994). A Theory For In Situ Stresses In Isotropic And Transverseley Isotropic Rock. In International Journal Of Rock Mechanics And Mining Sciences \& Geomechanics Abstracts, 31(1), 23 34.

15. Pergamon.

16. Hoek, E., \& Brown, E.T. (1997). Practical Estimates Of Rock Mass Strength. International Journal Of Rock Mechanics And Mining Sciences, 34(8), 1165-1186.

17. Deere, D.U. (1968). Geological Considerations. Rock Mechanics In Engineering Practice, Stagg And Zienkiewicz.

18. Geoconsult, M.S. (2004). Geotechnical Interpretative Report, Salzburg, 2004.

19. Bieniawski, Z.T. (1989). Engineering Rock Mass Classifications: A Complete Manual For Engineers And Geologists In Mining, Civil, And Petroleum Engineering. John Wiley \& Sons.

20. Celada, B., Tardáguila, I., Varona, P., Rodríguez, A., \& Bieniawski, Z.T. (2014). Innovating Tunnel Design By An Improved Experience-Based RMR System. In Proceedings Of The World Tunnel Congress, 1-9.

21. Hoek, E., \& Marinos, P. (2000). Predicting Tunnel Squeezing Problems In Weak Heterogeneous Rock Masses. Tunnels And Tunnelling International, 32(11), 45-51. 